\title{
Awareness Regarding Autism in Schools' Teachers at District Lower Dir, Khyber Pakhtunkhwa, Pakistan
}

\author{
Sana Ullah ${ }^{1}$, Muhammad Imtiaz Aqdas ${ }^{2}$, Nasrullah Khan ${ }^{2}$, Ghulam Nabi ${ }^{3, *}$, Tariq Aziz ${ }^{3}$ \\ ${ }^{1}$ Al-Azhar College of education, Timergara, District Lower Dir, Pakistan \\ ${ }^{2}$ Faculty of Business Administration, Al Khair University, AJK, Pakistan \\ ${ }^{3}$ MA Education, Faculty of education, Al Khair University, AJK, Pakistan
}

Copyright $(\mathcal{C} 2015$ by authors, all rights reserved. Authors agree that this article remains permanently open access under the terms of the Creative Commons Attribution License 4.0 International License.

\begin{abstract}
The present study was undertaken at District Lower Dir, Khyber Pakhtunkhwa, Pakistan in order to assess the knowledge and perceptions of schools teacher regarding autistics, in public and private schools. This cross sectional study was conducted through purposive sampling among 240 teachers using self-administered questionnaire. The questionnaire was having questions for investigating teachers' knowledge and perception about autism. The collected data was analyzed by using SPSS (Version 20). The results of the present study showed that $47.5 \%$ (114) teachers know about autism through media (64.04\% (73) through print media and $35.96 \%$ (41) through electronic media) while $8.75 \%$ (21) teachers know of it through trainings. Of the total $17.50 \%$ (21) public and $10.83 \%$ (13) private schools' teacher were of the opinion that autism is curable. A major portion, $42.92 \%$ (103) of the recruited teachers $(46.67 \%$ (56) public and $39.17 \%$ (47) private schools' teachers) said that there should be separate schools for autistics while $57.08 \%$ (137) of the total teachers (60.83\% (73) public and 53.33\% (64) private schools' teachers) were of the opinion that managing autistics comes with prior training. The current study concluded that there is a lack of awareness regarding autism among teachers from both the sectors, yet public schools' teachers were better aware. School implemented proper training, workshops and seminars are suggested to train teachers for autism diagnosis and teaching autistics accordingly.
\end{abstract}

Keywords Autism, Knowledge, Perception, Public, Private, Teachers

\section{Introduction}

Autism Spectrum Disorder (ASD) is a neurodevelopment disorder characterized by impaired communication both verbal and nonverbal, impaired social interface, repetitive and restricted behavioral pattern [1]. This life lasting condition initiates at birth or in between two and a half years of age. The affected children look pretty normal in appearance but use to spend more of their time in disturbed and puzzled behaviors, making them markedly different from other children [2].

Causes of autism is still unknown [3, 4]. Different studies conducted suggested strong genetic basis, however cannot be drawn at Mendelian mutation (Single gene) or abnormality of single chromosome [5, 6]. Risk factors may involve gender (males are more likely ( 3 to 4 times) to get autism as compare to females), age, history of family and may also involve other disorders such as epilepsy, Tourette's syndrome, tuberous sclerosis and fragile $\mathrm{X}$ syndrome [7]. Drug use during pregnancy is also identified as one of the risk factors, such as a study showed that during pregnancy use of valproic acid let to autism in neonates [8]. Other studies linked congenital rubella to autism $[9,10]$. During cerebral palsy, the rate of getting autism is quite high in children [11].

Autism sufferers may have different signs or symptoms. That's why most of the healthcare provider thinks autism as a spectral disorder [3]. Some autism sufferers use to have no eye contacts and seem much reserved while other display spasmodic engagements and might have uneven eye contacts, hugs and smile. Children may have varying verbal capabilities, fluctuating between nonverbally to advanced speech as well as intellectuality may vary from mental retardation to superior intellectuality depending on abode areas. Some autism sufferers may show typical advancement in specific skills and may even show excel performance in specific areas like music, art and puzzles. However, generally Autistics often spend more time in solitary play [12]. For early detection of autism, several screening tools have been developed. Kliegman [12] has given a complete description to these screening tools.

Different conducted studies have shown an approximate occurrence of $0.6-1 \%$ of autism spectrum disorder in neonates' populaces in North America, Europe and Asia [13]. An experiment conducted in different fifty states of US showed that state with better healthcare and educational expenditure got more suitability in autism diagnosis [14]. 
Country report of Pakistan on autism revealed prevalence of this spectrum disorder as 1 autistic child out of 120 children [15].

Unawareness among general public elevate the intensity of the autism severity and its diagnosis. Therefore current preliminary study was conducted at district Lower Dir Khyber Pakhtunkhwa Pakistan in order to investigate the teachers' awareness level regarding autism as they are the captains of the ships guiding students for future life and making them capable of leading out their potentialities for controlling their environment. This study will not only evaluate the recruited teachers' awareness but also help education institutes and organizations to increase awareness level regarding autism.

\section{Materials and Methods}

\subsection{Study Area}

Before merging into Pakistan in 1969, Dir was an independent state. In 1996 it was bifurcated into two districts, known as district Lower Dir and district Upper Dir [16]. District Lower Dir is located in northern part of Pakistan and is one among the vital districts of the province Khyber Pakhtunkhwa. It is situated with Longitudes and Latitudes of $34^{\circ}, 37^{\prime}$ to $35^{\circ}, 07^{\prime}$ North and $71^{\circ}, 31^{\prime}$ to $72^{\circ}, 14^{\prime}$ East respectively [17]. District Lower Dir is approximately 2700 feet (820 meter) above mean sea level [18]. Lower Dir is experiencing an annual rain fall of $1468.8 \mathrm{~mm}$ and $253.7 \mathrm{~mm}$ during December and March respectively [19]. It covers a total area of 1583 square kilometers [20]. District Lower Dir is having seven tehsils: Khal, Timergara, Balambat, Lal Qila, Adenzai, Samarbagh and Munda [21]. District Lower Dir is bounded by district Upper Dir to the Northern Side, by Bajaur Agency (Federally Administered Tribal Area) and Afghanistan to the Western side, by district Malakand to the Southern side and by district Swat to Eastern side [22]. Despite having a huge number of occupational castes Pushto/Pashto is the sole language spoken in the district. Figure 1 is showing District Lower Dir and its boundary, adopted as a modified form from Ullah et al. (2014e) [23].

\subsection{Data Collection Tool}

This was a cross-sectional study conducted among schools' teachers through simple random sampling (SRS) technique. A designed questionnaire having questions regarding different aspects such as symptoms, diagnosis and treatment of autism was administered to a total of 240 teachers, adopted from Arif et al. (2013) [24]. Half of the teachers were selected from public schools while half were from private schools.

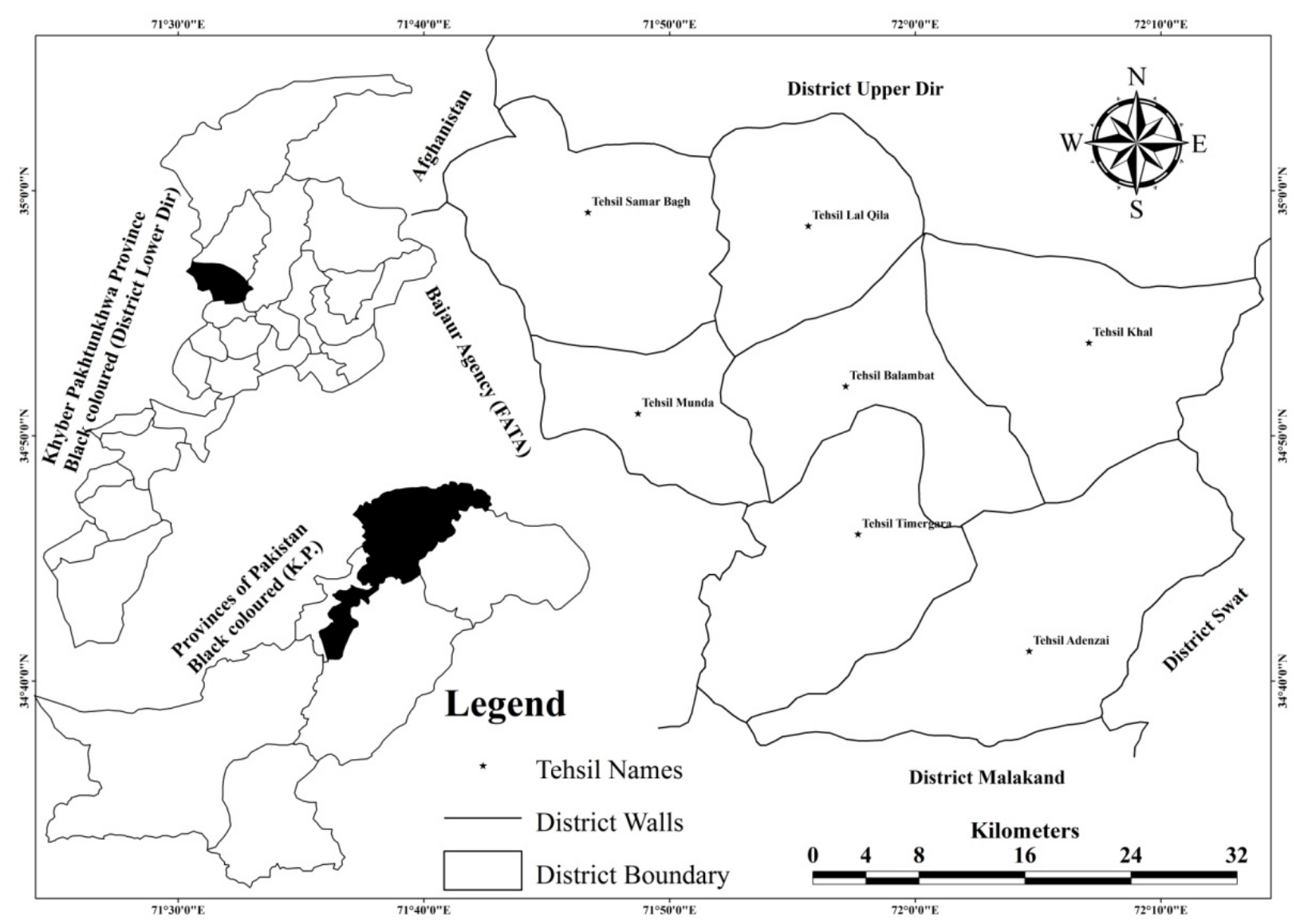

Figure 1. Map showing Study Area, its political division and geographic location. 


\subsection{Data Analysis}

The data was analyzed using SPSS (Version 20). The frequencies and percentages were calculated for both public and private teachers. The data was imperiled to Chi-Square test for finding difference between public and private schools' teachers as well as mean value for correct number of responses from both categories was also calculated. $P$ value of less than 0.05 was considered as significant.

\section{Results and Discussion}

Data gathered of 240 schools' teachers from both public and private sector was analyzed. The recruited respondents were belonging to different age groups, as shown in figure 2 . Both the teachers from public and private sectors were having different level of education, as shown in figure 3 . The recruited subjects were also having different professional educations, as shown in figure 4.

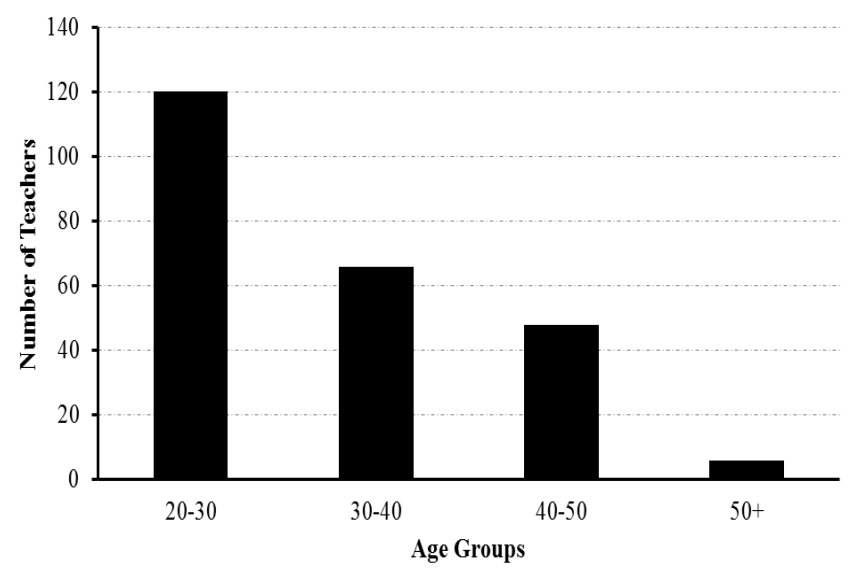

Figure 2. Age ranges of the recruited teachers

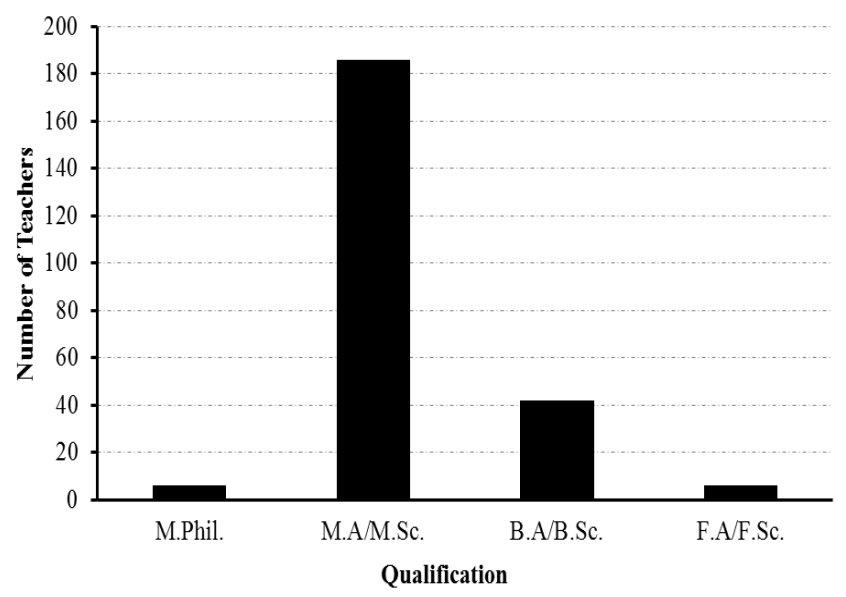

Figure 3. Qualification of the recruited teachers

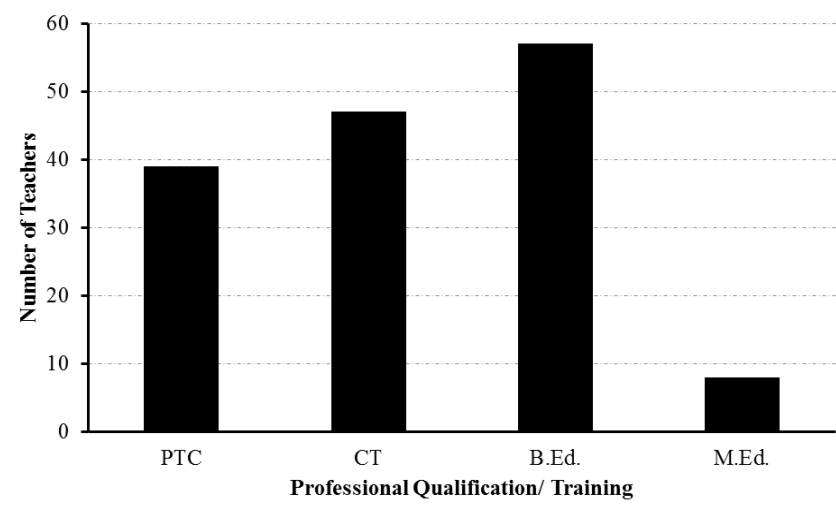

Figure 4. Professional Qualification/ Training of the recruited teachers

A total of 173 respondents acquired knowledge regarding autism, of which 114 acquired knowledge through media, 73 of print and 41 of electronic media, 21 teachers through trainings, 23 through seminars and workshops, 9 through fellow teachers and friends, and 6 through other sources. Figure 5 is showing source of information for the recruited teachers.

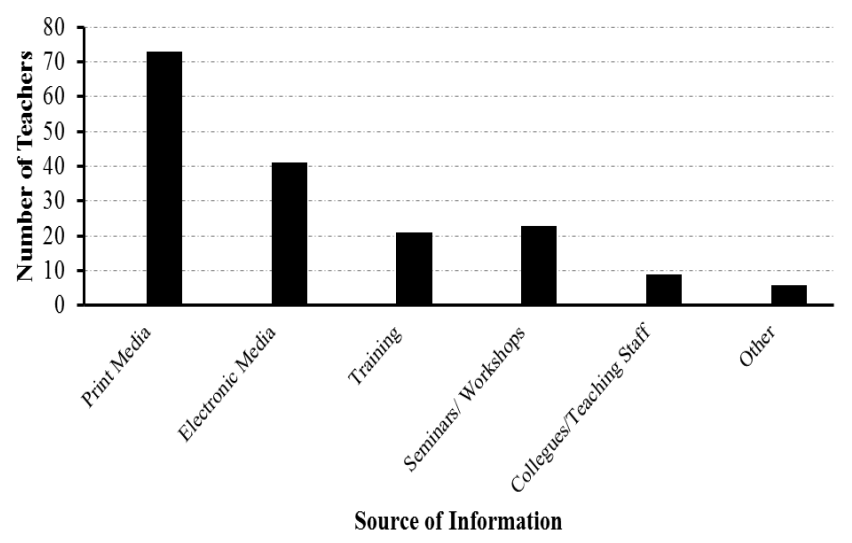

Figure 5. Source of Information for the recruited teachers regarding Autism

The questionnaire was consisted of 13 questions for evaluating knowledge and 3 questions regarding perception of the recruited subjects about autism (Table 1). Only 23 public and 17 private school teachers were aware of autism as an inherited disorder. According to 43 public and 39 private schools teachers, autism is a mental and learning disorder. Only a single question regarding autistic children's poor communication skills and expressing themselves, there was no statistical significant difference $\left(0.0743^{\text {ns }}\right)$ between the responses of public and private schools' teachers. Rest of the questions, were having statistical significance between the responses of public and private schools' teachers. In response to only two questions regarding general interests of an autistic children restriction and resistance to change, the teachers of private schools teachers were better aware. In response to other questions, public schools teachers were having more awareness. 
Table 1. Knowledge Regarding Autism

\begin{tabular}{|c|c|c|c|c|c|c|c|}
\hline \multirow{2}{*}{ Questions } & \multicolumn{2}{|c|}{ Public } & \multicolumn{2}{|c|}{ Private } & \multicolumn{2}{|c|}{ Total } & \multirow{2}{*}{$\begin{array}{c}\text { T-Test } \\
\text { P Value }\end{array}$} \\
\hline & $\mathrm{n}$ & \%age & $\mathrm{n}$ & \%age & $\mathrm{N}$ & \%age & \\
\hline Autism is an inherited disorder & 23 & 19.17 & 17 & 14.17 & 40 & 16.67 & $0.0018 * *$ \\
\hline Autism is a learning and mental disorder & 43 & 35.83 & 39 & 32.50 & 82 & 34.17 & $0.008 * *$ \\
\hline Signs of Autism show between 0 and 3 years & 23 & 19.17 & 20 & 16.67 & 43 & 17.92 & $0.0213^{*}$ \\
\hline An autistic child is not social & 70 & 58.33 & 63 & 52.50 & 133 & 55.42 & $0.0018 * *$ \\
\hline $\begin{array}{l}\text { An autistic child has poor communication skills and cannot express } \\
\text { himself }\end{array}$ & 75 & 62.50 & 69 & 57.50 & 144 & 60.00 & $0.0743^{\text {ns }}$ \\
\hline Verbally, an autistic child will have a hard time phrasing a sentence & 49 & 40.83 & 31 & 25.83 & 80 & 33.33 & $<0.0001 * * *$ \\
\hline Nonverbally, an autistic child does repetitive gestures to express himself & 41 & 34.17 & 21 & 17.50 & 62 & 25.83 & $<0.0001^{* * *}$ \\
\hline The attention span of an autistic child is deficient & 53 & 44.17 & 44 & 36.67 & 97 & 40.42 & $0.0003 * * *$ \\
\hline General interests of an autistic child are restricted & 51 & 42.50 & 60 & 50.00 & 111 & 46.25 & $0.0004 * * *$ \\
\hline An autistic child maintains minimal eye contact with others & 73 & 60.83 & 51 & 42.50 & 124 & 51.67 & $<0.0001 * * *$ \\
\hline General eating habits of an autistic child are normal & 34 & 28.33 & 31 & 25.83 & 65 & 27.08 & $0.0213 *$ \\
\hline An autistic child is resistant to change & 43 & 35.83 & 67 & 55.83 & 110 & 45.83 & $<0.0001 * * *$ \\
\hline An autistic child throws frequent bouts of anger & 41 & 34.17 & 37 & 30.83 & 78 & 32.50 & $0.008^{* *}$ \\
\hline
\end{tabular}

Table 2. Perception of the recruited teachers regarding Autism

\begin{tabular}{|c|c|c|c|c|c|c|c|}
\hline \multirow{2}{*}{ Questions } & \multicolumn{2}{|c|}{ Public } & \multicolumn{2}{|c|}{ Private } & \multicolumn{2}{c|}{ Total } & \multicolumn{2}{c|}{ T-Test } \\
\cline { 2 - 8 } & $\mathrm{n}$ & $\%$ age & $\mathrm{n}$ & $\%$ age & $\mathrm{N}$ & $\%$ age & P value \\
\hline Autism is not treatable using medication alone & 21 & 17.50 & 13 & 10.83 & 34 & 14.17 & $0.0006 * * *$ \\
\hline Autistic child should be taught in special school & 56 & 46.67 & 47 & 39.17 & 103 & 42.92 & $0.0004 * * *$ \\
\hline Managing a child with autism comes with prior training & 73 & 60.83 & 64 & 53.33 & 137 & 57.08 & $0.0004 * * *$ \\
\hline
\end{tabular}

Table 3. Comparison of correct responses among public and private teachers

\begin{tabular}{|c|c|c|c|c|}
\hline & $\begin{array}{l}\text { Total no. of questions (total no. of } \\
\text { responses) }\end{array}$ & $\begin{array}{c}\text { Total no. of correct responses } n \\
(\%)\end{array}$ & $\begin{array}{l}\text { Average no. of correct } \\
\text { responses per subject }\end{array}$ & $P$ Value \\
\hline \multicolumn{5}{|c|}{ Comparison of Knowledge } \\
\hline Public & $13(1560)$ & $619(39.68)$ & 5.158 & \multirow{2}{*}{$\begin{array}{c}<0.0001 \\
* * * \\
\end{array}$} \\
\hline Private & $13(1560)$ & $550(35.26)$ & 4.583 & \\
\hline Total & $13(3120)$ & $1169(37.47)$ & 4.87 & \\
\hline \multicolumn{5}{|c|}{ Comparison of Perception } \\
\hline Public & $3(360)$ & $150(41.67)$ & 1.25 & \multirow{2}{*}{$\begin{array}{c}<0.0001 \\
* * * \\
\end{array}$} \\
\hline Private & $3(360)$ & $124(34.44)$ & 1.03 & \\
\hline Total & $3(720)$ & $274(38.06)$ & 1.14 & \\
\hline \multicolumn{5}{|c|}{ Comparison of Knowledge and Perception (Combined) } \\
\hline Public & $16(1920)$ & $769(40.05)$ & 6.41 & \multirow{2}{*}{$\begin{array}{c}<0.0001 \\
* * *\end{array}$} \\
\hline Private & $16(1920)$ & $674(35.10)$ & 5.62 & \\
\hline Total & $16(3840)$ & $1443(37.58)$ & 6.01 & \\
\hline
\end{tabular}

Table 2 is showing perceptions of the teachers regarding autism. In response to all the three questions, public schools teachers were more aware of autism. There was a significant $P$ values between public and private schools teachers for all the questions. Of the total 21 public and 13 private school teachers perceived autism as not treatable with medicines only and requiring various cognitive and behavioral therapies while 56 public and 47 private school teachers were of the opinion that autistics should be taught in special schools. In response to the question regarding special training, 73 public and 64 private schools teachers think prior training for managing autistics.

The correct responses of the teachers for both knowledge and perceptions were compared, as given in Table 3. The responses of the teachers for both the categories were compared and categorized in right and wrong individually as well as combined. The average correct responses per public school teacher was 5.185 while 4.583 per private school teacher. There was a significant difference $(\mathrm{P}<0.00001 * * *)$ between the responses of public and private school teachers for questions about knowledge as well as perceptions regarding autism. There was a significant different $\left(\mathrm{P}<0.00001^{* * *}\right)$ between the combine response of public and private school teachers for questions in both categories. This comparative analysis showed that public schools teachers were having better knowledge and perception about autistics when compared to teachers from public sector.

Currently autism is being diagnosed 1/150 children [13]. 
On account of an increased prevalence, populaces should be aware so that it can be initiated with a therapy at earlier age. Previous such as conducted at Karachi [24] and Singapore [25] revealed lower level of awareness of teachers regarding autism. Similarly these studies showed that only $37.47 \%$ questions were responded correctly, which clearly depict that majority of the recruited subjects were unaware of the key facts regarding autism.

Autism diagnosis is highly advantageous at early age especially in development of intellectuality of the children and enables initiation of proper therapy. Children used to be in interaction with school teachers therefore teachers play a key role at their early stage of life. Teachers' ability to identify autistic, at early age; result in advantages on long term as Autism management include medication accompanied by cognitive and behavioral therapies [26].

\section{Conclusions}

Our study concluded that there is lack of awareness regarding autism in schools teachers of district lower Dir, Khyber Pakhtunkhwa Pakistan. It is clear as bright day light that coping with autism require proper management and identification of autistic at earlier age showed to be more beneficial. As teachers are in interaction with students since very early therefore there must be appropriate training programs, seminars and workshops for teachers on autistics management, diagnosis and pointing out autistic children and teaching them according to their need and mentality.

\section{REFERENCES}

[1] APA (American Psychiatric Association), Diagnostic and Statistical Manual of Mental Disorders, 4th edition, 2000.

[2] "Is it autism?" Autism Research institute, http://www.autism.com/index.php/is it autism.

[3] Autism: Mediline Plus, http://www.nlm.nih.gov/medlineplus/ autism.html.

[4] CJ. Newschaffer, LA. Croen, JD Daniel The epidemiology of autism spectrum disorders. Annual Review of Public Health, 28;235-258, 2007.

[5] BS. Abrahams, DH. Geschwind, Advances in autism genetics: on the threshold of a new neurobiology. Nature Reviews Genetics, 9:341-355, 2008.

[6] R. Muhle, SV. Trentacoste, I. Rapin. The genetics of autism. Pediatrics, 113:472-486, 2004.

[7] MayoClinicmayoclinic.com/health/autism/Ds00348/DSECTI $\mathrm{ON}=$ Symptoms

[8] G. Williams, J. King, M. Cunningham, M. Stephan, B. Kerr, JH. Hersh. Fetal valproate syndrome and autism: additional evidence of an association. Developmental Medicine and Child Neurology, 43, 202-206, 2001.
[9] S. Chess, P. Fernandez, S. Korn, Behavioral consequences of congenital rubella. Journal of Pediatrics, 93:699-703, 1978.

[10] BE. Berger, AM. Navar-Boggan, SB. Omer. Congenital rubella syndrome and autism spectrum disorder prevented by rubella vaccination-United States, 2001-2010. BMC Public Health, 11, article, 340, 2011.

[11] E. Fombonne. The prevalence of autism. Journal of the American Medical Association, 289:87-89, 2003.

[12] RM. Kliegman, RE. Beahrman, HB. Jenson, BM. D. Stanton, Nelson Textbook of Paedriatics, vol. 1, 2007.

[13] CDC_-Data and Statistics, "Autism spectrum disorders,"http://www.cdc.gov/ncbddd/autism/data.html.

[14] DS. Mandell, R. Palmer. Differences among states in the identification of autistic spectrum disorders. Archives of Pediatrics and Adolescent Medicine,159: 266-269, 2005.

[15] MA. Khan, Pakistan Country Report-Autism.

[16] U. Sana. GIS Integrated Approach for Assessing Drinking Water Quality. VDM Publishing Heinrich-Böcking-Str. 6-8 D - 66121 Saarbrücken Germany, 24-25, 2014.

[17] U. Sana, Hasan, Z., Zuberi, A., Younus, N. Rauf, S. Comparative study on body composition of two Chinese carps, common carp (Cyprinus carpio) and silver carp (Hypophhthalmichthys molitrix). Global Veterinaria, 13: 867-876, 2014.

[18] U. Sana, Javed, M.W., Rasheed, S.B., Jamal, Q., Aziz, F. Ullah, S. Assessment of groundwater quality of district Dir Lower Pakistan. International Journal of Biosciences, 4: 248-255, 2014.

[19] U. Sana, Hasan, Z., Ahmad, S., Rauf, M. Khan, B. ichthyofaunal diversity of rhound stream at district Lower Dir, Khyber Pakhtunkhwa Pakistan. International Journal of Biosciences, 4: 241-247, 2014.

[20] U. Sana. The Ichthyofaunal diversity, relative abundance, Physico chemical analysis and the estimation of biodiversity index of river Panjkora, district Dir lower, Khyber Pakhtunkhwa. M.Sc. Thesis (Unpublished). Department of Zoology, University of Peshawar, Khyber Pakhtunkhwa, Pakistan, 2013.

[21] U. Sana, Hasan, Z., Aziz, F., Amir, I. Muhammad, I. Diversity of Edible fishes at Rhound stream District Dir Lower, Khyber Pakhtunkhwa Pakistan. International Journal of Innovation and Applied Studies, 10: 466-472, 2014.

[22] U. Sana, Javed, M.W., Shafique, M. Khan, S.F. An integrated approach for quality assessment of drinking water using GIS: A case study of Lower Dir. Journal of Himalayan Earth Sciences, 47: 163-174, 2014.

[23] MA. Arif, A. Niazy, B. Hassan, F. Ahmed. Awareness of Autism in Primary School Teachers. Autism Research and Treatment, 1-5, 2013.

[24] WB. Lian, SHK. Ying, SCH. Tean, DCK. Lin, YC. Lian, HL. Yun. Pre-school teachers' knowledge, attitudes and practices on childhood developmental and behavioural disorders in Singapore. Journal of Paediatrics and Child Health, 44:187194, 2008.

[25] SM. Myers, CP. Johnson, PH. Lipkin. Management of children with autism spectrum disorders. Pediatrics, 120:1162-1182, 2007. 